\title{
The Mediation Effect of Corporate Image and Corporate Attitude on the Relationship between the Social Responsibility Activity of Sports Enterprises and the Loyalty of Customers
}

\author{
Kyongmin Lee ${ }^{1}$, YongKoo $\mathrm{Noh}^{2}$ and Kang-Won You ${ }^{3}$ \\ ${ }^{1}$ Dankook University, Department of Sport Management, Cheonan, Korea, ${ }^{2}$ Korea Institute of Sport Science, Department of Policy Development, \\ Seoul, Korea, ${ }^{3}$ Jeonju University, Department of Soccer, Jeonju, Korea
}

\begin{abstract}
The direct causal relationship between Corporate Social Responsibility activity and customer loyalty has been dealt with in many research studies, but there is a lack of discussion on the parameters that may affect the relationship between the two variables. Thus, this research selected corporate image and corporate attitude as parameters that could affect the relationship between the social responsibility activity of sports enterprises and customer loyalty and empirically investigated the relationship of each variable. For this research, the survey targeted 300 students of a four-year university located in the Gyeonggi-do, Chungcheong-do, and Jeolla-do regions of the Republic of Korea using a convenience sampling method. The main results of the hierarchical multiple regression analysis based on the mediation effect analysis method proposed by Baron and Kennedy are as follows: First, the social responsibility activity of sports enterprises was found to have a positive impact on the following factors: 1) corporate loyalty, 2) corporate image, 3) corporate attitude. Second, the corporate image was found to have a positive impact on customer loyalty. Third, the corporate attitude was found to have a positive impact on customer loyalty. Fourth, the social responsibility activity of sports enterprises was found to have a positive impact on customer loyalty through the corporate attitude and corporate image.
\end{abstract}

Keywords: corporate attitude, corporate image, customer loyalty, social responsibility activity of sports enterprises

\section{Introduction}

Necessity \& purpose of the research

It is a deniable fact that private enterprise has contributed much to the material affluence of society. However, as the primary purpose of an enterprise gradually degenerates as profit-seeking, it receives continuous criticism for neglecting many social issues, such as the environment and income inequality (Seong \& Seo, 2010). In the sense that society has given legal personhood to corporations, it can be said that companies are not the property of a particular group, but rather the property of society. Accordingly, there has been a growing global demand for the implementation of CSR (Corporate Social Responsibility) requiring corporations to be actively involved in solving social problems in the process of generating profits (Zu \& Song, 2009).

According to the advent of a hyper-connected society characterized by openness, cooperation, and connectivity, various stakeholders are involved in the corporate management pro-

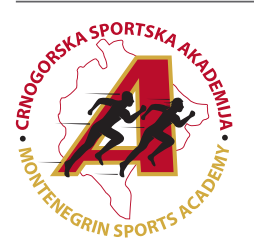

Correspondence:

Y. Noh

Korea Institute of Sport Science, Department of Policy Development, 727 Hwarang-ro, Nowon-gu, Seoul, Korea

E-mail: ynoh@kspo.or.kr 
cess, and their voices are growing (Anggusti, 2018). Therefore, the involvement of enterprises in solving social problems, such as solving employment problems in communities that are of interest to corporate stakeholders, improving the welfare of employees, and eco-friendly management for the global environment, is not only a required condition to create a sustainable enterprise but also an important management strategy for enterprise growth.

Under these trends, studies on the impact of CSR activity on corporate performance have been actively performed in various fields. For example, the research of Hsu (2018) showed that the social responsibility activity of mobile communication corporations has a positive effect on consumer satisfaction, corporate image, and customer loyalty and that CSR has a positive effect on corporate image and customer loyalty by mediating consumer satisfaction. In the fields of sports, it has been proven that CSR activity can be utilized as an essential marketing tool in securing loyal customers. A study by $\mathrm{Oh}$ (2016) on the relationship between the social responsibility and the customer loyalty of the professional basketball team found that ethical responsibility among the CSR activity types had a positive effect on the repurchase intention and oral effects and that ethical and economic responsibilities had a positive effect on the corporate preferences and the formation of low price sensitivity. These research results show that CSR activity can not only have a positive effect on consumer belief and belief for its products and services, emotional evaluation and purchasing behaviour, but also help maintain amicable relationships with existing customers over the long-term.

The fact that CSR activity is an essential determinant of customer loyalty and that competition between companies or products is intensified provides significant marketing implications: because there is a tendency that customers who have high loyalty prefer products and services of a particular company even in the situation of inter-company competition (Han, Y. Kim, \& E.K. Kim, 2011). Thus, through CSR activity, the corporation enables existing customers to continue to be immersed psychologically or emotionally for the corporation, which will contribute ultimately to profit creation (Yusof, Manan, N.A. Kassim, \& N.A.M. Kassim, 2015).

However, as mentioned by Martinez and Bosque (2013), most research on the relationship between CSR and customer loyalty has identified a direct causal relationship between the two variables. Also, empirical discussion on the parameters between the two variables was insufficient. Thus, efforts for defining the theoretical model by finding the existing parameters between the two variables will be helpful to understand the CSR effects in the relationship between CSR activity and customer loyalty from a multi-dimensional view and establish an efficient marketing strategy for improving the customer loyalty.

Based on the prior research, corporate image and corporate attitude were selected as parameters that could affect the relationship between CSR and customer loyalty in this research. CSR activity contributes to the formation of positive corporate image (Hsu, 2018), and the corporate image is identified as critical leading variables in the formation of customer loyalty (Choo \& Kim, 2012). In addition, CSR activity affects the attitudes of customers toward the corporation (Distefano \& Pisano, 2016), and the corporate attitude is reported as a cause of direct influence on customer loyalty (Doorn, Onrust, Verhoef, \& Bügel, 2017). Therefore, the purpose of this re- search is to empirically analyse the effect corporate image and corporate activity have on the relationship between the social responsibility activity of sports enterprises and customer loyalty.

\section{Research hypothesis}

CSR activity is known to play a critical role in securing and maintaining customers who have high loyalty. In a study that Martinez and Bosque (2013) performed for hotel customers, the social responsibility activity of a hotel was found to have a positive effect on customer loyalty by mediating reliability, consumer-business identification and satisfaction. A study of Pérez and Bosque (2015) for customers of a bank also found that the social responsibility activity of a bank had a positive effect on customer satisfaction, word-or-mouth effectiveness and repurchasing intention. Therefore, based on these theoretical grounds, the hypothesis was established as follows:

Hypothesis 1 . The social responsibility activity of sports enterprises will have a positive effect on customer loyalty.

In a society in which competition between companies or products is intensifying, and competition is based on nonprice factors rather than price, consumers consider the company image in making their purchase decisions (Jeong, Kim, \& Park, 2012). In light of a prior research of the relationship between CSR and corporate image, the research results of Lee, Kim, and Jin (2015) showed that there was a positive definition relationship between CSR and the corporate image and that relative influence of marketing communication CSR activity was greater than other CSR types. Therefore, based on this theoretical ground, the next hypothesis was established:

Hypothesis 2. The social responsibility activity of sports enterprises will have a positive effect on the corporate image.

In light of the prior research on CSR activity and corporate attitude, Pino, Amatuli, De Angelis, and Peluso (2015) found that the higher the consumer awareness of corporate charitable and legal social responsibility, the higher the favourable attitude toward the enterprise; Doorn, Onrust, Verhoef, and Bügel (2017) also found that CSR had a positive effect of consumers toward corporate attitudes. Therefore, based on these theoretical grounds, the next hypothesis was established:

Hypothesis 3. The social response activity of sports enterprises will have a positive effect on the corporate attitude of consumers.

Corporate image is known to be a critical variable for maintaining and raising customer loyalty. In light of research on the relationship between company image and customer loyalty, Kim and Lee's (2010) research on a Korean mobile communication company showed that corporate image is a critical leading variable for the formation of customer loyalty; Choo and Kim (2012) also found that the better the image of a restaurant franchise chain, the higher the customer loyalty. Therefore, based on these theoretical grounds, the next hypothesis was established:

Hypothesis 4 . The corporate image will have a positive effect on customer loyalty.

Given that the customer attitude toward the enterprises formed through information, and that experience affects the loyalty toward the enterprises (Y.M. Kim \& S.Y. Kim, 2011), forming a positive belief and favourable feeling of customers toward enterprises, can be seen as a prerequisite for raising customer loyalty. In the research of Hasbullah (2015), attitude was found to have a high positive correction of 0.867 with loyalty intention. Thus, based on these theoretical grounds, the 
next hypothesis was established:

Hypothesis 5. The corporate attitude will have a positive effect on customer loyalty.

Meanwhile, corporate attitude and corporate image are found to be mediated between the CSR and customer loyalty. In the research of Urandelger, Bae, and Lee (2014) on the relationship between the corporate social responsibility, customer satisfaction, and customer loyalty, the CSR activity of enterprises was found to have a positive effect on customer satisfaction through the corporate image. Thus, based on this theoretical ground, the next hypothesis was established as follows:

Hypothesis 6. The social responsibility activity of sports enterprises will have a positive effect on customer loyalty through the corporate image and corporate attitude.

\section{Methods}

Participants

The population of this research was configured as university students who are aware of the social responsibility activity of sports enterprises, and a survey was performed using a convenient sampling method with four-year university students as a sample located in the Gyeonggi-do, Chungcheong-do, and Jeolla-do regions in the Republic of Korea. A total of 350 questionnaires were distributed, and the retrieved 300 questionnaires, excluding insincere responses, were used for final analysis.

\section{Measures}

To measure the social responsibility of sports enterprises, a questionnaire used by Jung and Kim (2012) was modified for the present study. It was a single factor questionnaire composed of four questions. Its reliability was found to have an internal consistency of $\alpha=.977$. To measure the corporate image, the questionnaire used by Wang and Han (2017) was modified for the present study. The corporate image was a single factor, consisting of three total questions. The reliability of the questionnaire was found to have an internal consistency of $\alpha=.907$. To measure the corporate attitude, the questionnaire used by $\mathrm{Oh}$ and $\mathrm{Cha}$ (2017) was modified. The corporate attitude was a single factor, consisting of three total questions. The reliability of the questionnaire was found to have an internal consistency of $\alpha=.819$. To measure customer loyalty, a questionnaire used by Yoon and Ryu (2014) was modified for the present study. Customer loyalty was a single factor, consisting of four questions. The reliability of the questionnaire was found to have an internal consistency of $\alpha=.927$. The questionnaires used in this research, except for the general characteristics of the research participants, were measured as five points of a Likert scale.

\section{Data analysis}

The collected data in this research were analysed using SPSS 23.0. Reliability analysis and correlations analysis were performed to identify the reliability of the measurement items and the correlations among the measurement variables respectively. Next, to verify whether corporate image and corporate attitude act as parameters in the relationship between CSR and customer loyalty of sports enterprises, a hierarchical multiple regression analysis was performed using the mediation effect analysis method proposed by Baron and Kenny (1986).

\section{Results \\ Correlations results}

As shown in Table 1, significant positive correlations at $\mathrm{p}<.01$ level were found, among the social responsibility activity of sports enterprises, corporate image, corporate attitude, and customer loyalty.

Table 1. Correlations between Social Responsibility of Sports Enterprises, Corporate Image, Corporate Attitude, and Customer Loyalty $(\mathrm{N}=300)$

\begin{tabular}{|c|c|c|c|c|c|c|}
\hline Variable & $M$ & $S D$ & 1 & 2 & 3 & 4 \\
\hline CSR & 3.59 & 0.49 & 1 & & & \\
\hline Corporate Image & 3.82 & 0.50 & $0.490^{* *}$ & 1 & & \\
\hline Corporate Attitude & 3.80 & 0.48 & $0.424^{* *}$ & $0.411^{* *}$ & 1 & \\
\hline Customer Loyalty & 3.93 & 0.55 & $0.481^{* *}$ & $0.389^{* *}$ & $0.459^{* *}$ & 1 \\
\hline
\end{tabular}

\section{Hypothesis testing}

As shown in Table 2, in Step 1, the CSR activity was found to have a significant impact on the corporate image $(\beta=.490, p<.001)$; in Step 2, the effects of CSR activity on customer loyalty were also found to be significant $(\beta=.481$, $\mathrm{p}<.001$ ). In addition, in Step 3, the corporate image was found to have a significant impact on customer loyalty $(\beta=.202, \mathrm{p}<.001)$. In conclusion, since the regression coefficient $(\beta=.481)$ of CSR activity derived from Step 2 is greater than the regression coefficient ( $\beta=.382)$ of CSR activity derived from Step 3, the mediation effect of corporate image was identified as being significant in the relationship between the social responsibility activity of sports enterprises' activity and customer loyalty.

Table 2. Corporate Image's Mediating Effect on the Relationship between Social Responsibility Activity of Sports Enterprises and Customer Loyalty $(\mathrm{N}=300)$

\begin{tabular}{ccccccc}
\hline Step & Variable & $\boldsymbol{B}$ & SE $\boldsymbol{B}$ & $\boldsymbol{\beta}$ & $\boldsymbol{F}$ & $\boldsymbol{R}^{2}$ \\
\hline 1 & CSR activity $\rightarrow$ Corporate Image & .499 & .052 & $.490^{* * *}$ & $93.920^{* * *}$ & .240 \\
2 & CSR activity $\rightarrow$ Customer Loyalty & .544 & .057 & $.481^{* * *}$ & $89.693^{* * *}$ & .231 \\
& CSR activity $\rightarrow$ Customer Loyalty & .432 & .065 & $.382^{* * *}$ & & $52.784^{* * *}$ \\
\multirow{2}{*}{3} & Corporate Image $\rightarrow$ Customer Loyalty & .223 & .063 & $.202^{* * *}$ & .262 \\
\hline
\end{tabular}

$* * * p<.001$ 
As shown in Table 3, in Step 1, the CSR activity was found to have a significant impact on the corporate attitude $(\beta=.424$, $\mathrm{p}<.001)$; in Step 2, the effects of CSR activity on customer loyalty were found to be significant $(\beta=.481, \mathrm{p}<.001)$. In addition, in Step 3, the corporate attitude was also found to have a significant impact on customer loyalty $(\beta=.359, \mathrm{p}<.001)$. In con- clusion, since the regression coefficient $(\beta=.481)$ of CSR activity derived from Step 2 is greater than the regression coefficient $(\beta=.349)$ of CSR activity derived from Step 3 , the mediation effect of corporate attitude was identified to be significant in the relationship between the social responsibility activity of sports enterprises and the customer loyalty.

Table 3. Corporate Attitude's Mediating Effect on the Relationship between Social Responsibility Activity of Sports Enterprises and Customer Loyalty $(\mathrm{N}=300)$

\begin{tabular}{ccccccc}
\hline Step & Variable & $\boldsymbol{B}$ & $\boldsymbol{S E} \boldsymbol{B}$ & $\boldsymbol{\beta}$ & $\boldsymbol{F}$ & $\boldsymbol{R}^{\mathbf{2}}$ \\
\hline 1 & CSR activity $\rightarrow$ Corporate Attitude & .415 & .051 & $.424^{* * *}$ & $65.201^{* * *}$ & .180 \\
2 & CSR activity $\rightarrow$ Customer Loyalty & .544 & .057 & $.481^{* * *}$ & $89.693^{* * *}$ & .231 \\
& CSR activity $\rightarrow$ Customer Loyalty & .395 & .060 & $.349^{* * *}$ & & \\
3 & Corporate Attitude $\rightarrow$ Customer Loyalty & .359 & .061 & $.311^{* * *}$ & & \\
\end{tabular}

${ }^{* * *} \mathrm{p}<.001$

\section{Discussion}

First, the CSR activity was found to have a positive effect on the customer loyalty of university students. The enterprise performing social responsibility activity is recognized by consumers as a corporation performing the right roles and functions that society expects (Vahdati, Mousavi, \& Tajik, 2015). Consumers have a favourable attitude toward corporates participating in social responsibility activity and tend to trust and prefer their products and services (Oh, 2016). Accordingly, sports enterprises need to establish a CSR strategy to prepare the policies and procedures that integrate social, environmental, ethical, human rights or consumer interests into the business operation and core strategy to raise the customer loyalty.

Second, the CSR activity was found to have a positive effect on the corporate image of university students toward sports enterprises. The reason that CSR activity has a positive effect on the evaluation and attitude for customers is because the focus of such activity is set in a direction balancing the vision and goal of the enterprises and the interests and welfare of society, rather than the pursuit of the interests of enterprises (Heikkurinen \& Ketola, 2012). Through CSR activity, an enterprise can create an image of a good corporate citizen that aims for social value, such as managing an ethical responsibility, protecting human rights and preparing protective guards for the environment, rather than merely pursuing the material goal of profit creation through the provision of products and services (Seong, 2017). Thus, to improve the corporate image of consumers toward sports enterprises, the sports enterprises need to participate actively in social issues, such as job problems in the community, improvement of employee welfare , protection of the global environment, protection of human rights, and opposition to animal testing.

Third, the CSR activity was found to have a positive effect on the attitude of university students toward sports enterprises. This result is in line with the studies (Distefano \& Pisano, 2016; Pino et al., 2015) that insisted that CSR activity has a positive effect on the response and attitude of customer toward the enterprises. Thus, providing the public with information that the purpose of the existence of enterprises is not just to pursue profit but to strive to create a better world for those who have difficulties; CSR activity can bring positive changes in the consumer's cognitive, emotional and behavioural attitudes toward enterprises (Distefano \& Pisano, 2016).

Fourth, the image of sports enterprises was found to have a positive effect on the loyalty of university student customers. The key role of corporate image is to bring a positive attitude of consumer toward the products and services provided by the enterprises (Stoyanov, 2017). The image of consumers toward sports enterprises can be formed by the quality level, the service level of salespersons (Agyei \& Kilika, 2014), the philosophy and vision of the enterprises (Dowling, 1986), and the marketing activities deployed by the enterprise (Barich \& Kotler, 1991). The image of sports enterprises formed by these corporate image determinants affects the formulation and change of the attitude on products and services provided by the sports enterprises, and the attitude is ultimately shown as a psychological driver affecting the behavioural intention. Therefore, to raise the loyalty of consumers, sports enterprises need to endeavour to form a positive corporate image.

Fifth, the attitude of university student consumers toward sports enterprises was found to have a positive effect on the loyalty of university student customers. It is consistent with the result of Y. M Kim and S. Y. Kim's study (2011) that reported that the more favourable attitude of the consumer toward the enterprises, the higher the customer loyalty toward the products and services of corresponding enterprises. Thus, sports enterprises need to endeavour to have a favourable attitude toward their own enterprises to raise the loyalty of customers.

Sixth, the corporate image and the corporate attitude was found to be mediated in the relationship between the CSR activity and the customer loyalty. These results show that the social responsibility activity of sports enterprises contributes to the formation of a favourable image and attitude of university student consumers toward the corresponding enterprise, and that these positive corporate images and corporate attitudes play an essential role in the improvement of customer loyalty. Thus, it seems that sports enterprises need to deploy the CSR activity on various social issues in which the public is interested in improving customer loyalty and that the strategic plans are necessary to form positive corporate image and corporate attitude.

The results of this research show that the CSR activity of sports enterprises not only has a positive effect on the image and attitude of customers toward enterprises but also contributes much to the improvement of customer loyalty. However, this study has the following limitations. First, as the survey target of this research is limited to university students in some regions of Korea, the results cannot be generalised to consumers of all ages in other countries. Second, in this research, the 
corporate image and corporate attitude were selected as parameters of CSR activity and customer loyalty based on prior research. In further research, it seems necessary to explore

\section{Acknowledgements}

There are no acknowledgements.

\section{Conflict of Interest}

The authors declare that there are no conflicts of interest.

Received: 19 November 2019 | Accepted: 12 January 2020| Published: 01 February 2020

\section{References}

Anggusti, M. (2018). Empowering law and strategy of CSR in the wake of the $4^{\text {th }}$ Industrial Revolution at Indonesia. International Journal of business, Economics and Law, 15(4), 1-6.

Barich, H., \& Kotler, P. (1991). A framework for marketing image marketing image management. Sloan Management Review, 32(2), 94-104.

Baron, R.M., \& Kenny, D.A. (1986). The moderator-mediator variable distinction in social psychological research: conceptual, strategic, and statistical considerations. Journal of Personality and Social Psychology, 51(6), 1173-1182

Choo, S.W. \& Kim, H.B. (2012). The effect on the corporate society responsibility to corporate image and loyalty in the food-service franchise: Focus on the university student of hotel and food-service dept. Journal of tourism \& Leisure Research, 24(3), 525-547.

Distefano, A. \& Pisano, V. (2016). The effect of corporate social responsibility in consumers' attitude towards waste treatment facilities. Electronic Journal of Management, 3, 1-32.

Doorn, J., Onrust, M., Verhoef, P., \& Bügel, M.S. (2017). The impact of corporate social responsibility on customer attitudes and retention: The moderating role of brand success indicators. Marketing Letters, 28(4), 607-619.

Dowling, G.R. (1986). Managing your corporate images. Industrial Marketing Management, 15(2), 109-115.

Han, H., Kim, Y., \& Kim, E.K. (2011). Cognitive, affective, conative, and action loyalty: Testing the impact of inertia. International Journal of Hospitality Management, 30(4), 1008-1019.

Hasbullah, N. (2015). Members' attitude and loyalty intention in the Malaysian consumer co-operatives. International Journal of Business and Social Science, 6(12), 187-193.

Heikkurinen; P., \& Ketola, T. (2012). Corporate responsibility and identity: From a stakeholder to an awareness approach. Business Strategy and the Environment, 21(5), 326-337.

Hsu, S.L. (2018). The effects of corporate social responsibility on corporate image, customer satisfaction and customer loyalty: An empirical study on the telecommunication industry. The International Journal of Social Sciences and Humanities Invention, 5(5), 4693-4703.

Jeong, E.S., Kim, D.H., \& Park, B.J. (2014). Effects of corporate socia responsibility on corporate image and purchase intention. Proceedings of the DAEHAN Association of Business Administration, Korea, 743-757.

Jung, J.H., \& Kim, Y. M. (2012). Influence of ethical value and social responsibility of a sporting goods business on corporate commitment, person-brand fit and brand loyalty. The Korean Journal of Physical Education, 51(5), 385-398.

Kim, Y.E., \& Lee, J.W. (2010). Relationship between corporate image and customer loyalty in mobile communications service markets. Africa Journal of Business Management, 4(18), 4035-4041. more various parameters, such as the identification of sports teams affecting the relationship between CSR activity and customer loyalty.

Kim, Y.M., \& Kim, S.Y. (2011). The relationship between corporate social responsibility, consentaneity of consumer and brand image, attitude toward brand and brand loyalty: Positive and negative information. Journal of Sport and Leisure Studies, 45(1), 315-328.

Lee, D.H., Kim, C.J., \& Jin, C.H. (2015). The role of CSR activities on building corporate image and customer loyalty. Journal of International Trade \& Commerce, 11(6), 67-91.

Martinez, P., \& Bosque, I.R. (2013). CSR and customer loyalty: The roles of trust, customer identification with the company and satisfaction. International Journal of Hospitality Management, 35, 89-99.

Oh, J.S. (2016). The analysis of the relationship between the professional basketball team's CSR activity, corporate image, loyalty and purchasing intention. The Korean Journal of Sport, 14(4), 133-145.

Oh, Y., \& Cha, H. (2017). The effect of CSR type, CSR fit and ethnocentrism of multinational corporations on CSR motivation and corporate attitude: Focusing on persuasion knowledge model. The Korean Journal of Advertising, 28(2), 139-170.

Pérez, A., \& Bosque I.R. (2015). Corporate social responsibility and customer loyalty: Exploring the role of identification, satisfaction and type of company. Journal of Services Marketing, 29(1), 15-25.

Pino, G., Amatulli, C., \& De Angelis, M., \& Peluso, A.M. (2015). The influence of corporate social responsibility on consumers' attitudes and intentions toward genetically modified foods: Evidence from Italy. Journal of Cleaner Production, 112(Part 4), 2861-2869.

Seong, H.S. (2017). A study on the effects of global corporate social responsibility on corporate image, relation orientation, and performance: Focusing on the Korean food service industry in Vietnam. International Journal of Tourism and Hospitality Research, 31(8), 207-221.

Seong, H.S., \& Seo, D.G. (2010). A study on the influence of corporate social responsibility (CSR) on corporate image and performance. Journal of Korea Service Management Society, 11(2), 25-47.

Stoyanov, P. (2017). Corporate social responsibility and corporate image building. Economics and Finance, N8, 4-11.

Urandelger, G., Bae, B.R., \& Lee, D.S. (2016). The impacts of corporate social responsibility on customer satisfaction and loyalty: The mediating roles of corporate image and reputation, the moderating role of switching costs. Journal of Industrial Economics and Business, 29(3), $1205-1230$.

Vahdati, H., Mousavi, N., \& Tajik, Z.M. (2015). The study of consumer perception on corporate social responsibility towards consumers attitude and purchase behaviour. Asian Economic and Financial Review, 5(5), 831-845.

Wang, S.M. \& Han, H.S. (2017). The effects of airlines' CSR activities on corporate image and brand preference: From the perspectives of job seekers. Korean Journal of Hospitality \& Tourism, 26(6), 69-85.

Yoon, K, \& Ryu, J.Y. (2014). The dual mediation effect of CSR trust on consumer loyalty: The role of CSV perceptions, corporate attitude and consumer-company identification. The Korean Journal of Advertising 25(6), 7-26.

Yusof, J.M., Manan, H.A., Karim, N.A., \& Kassim, N.A.M. (2015). Customer's loyalty effects of CSR initiatives. Social and Behavioral Sciences, 170, 109119.

Zu, L., \& Song, L. (2009). Determinants of managerial values on corporate social responsibility: Evidence from China. Journal of Business Ethics, 88(Supplement 1), 105-117. 